\title{
Impact of digital services of hybrid cloud-based learning environment on efficiency of education
}

\section{Impacto dos serviços digitais do ambiente de aprendizagem baseado em nuvem híbrida na eficiência da educação}

\section{Impacto de los servicios digitales del entorno de aprendizaje híbrido basado en la nube en la eficiencia de la educación}

\author{
Natalia Kovalevskaia1 ${ }^{\text {(iD }}$, Emma Nikolaevna Gilyazeva² (iD), Olga Fedorovna Lobazova ${ }^{3}$ (D), \\ Irina Albertovna Duborkina ${ }^{4}$ iD, Antonina Pavlovna Sokolova ${ }^{5}$ ic
}

\footnotetext{
${ }^{1}$ Saint Petersburg State University, St. Petersburg, Russian Federation.

${ }^{2}$ Kazan Federal University, Kazan, Russian Federation.

${ }^{3}$ Russian State Social University, Moscow, Russian Federation.

${ }^{4}$ Higher School of Business, Management, and Law, Cherkizovo, Pushkinsky district, Moscow region, Russian Federation.

${ }^{5}$ Russian State University of Tourism and Service, Cherkizovo, Pushkinsky district, Moscow region, Russian Federation.
}

Corresponding author:

Natalia Kovalevskaia

Email: nk@bossner.de

How to cite: Kovalevskaia, N., Gilyazeva, E. N., Lobazova, O. F., Duborkina, I. A., \& Sokolova, A. P. (2021). Impact of digital services of hybrid cloud-based learning environment on efficiency of education. Revista Tempos e Espaços em Educação, 14(33), e15297. http://dx.doi.org/10.20952/revtee.v14i33.15297

\begin{abstract}
This paper aims to analyse the impact of the hybrid cloud-based learning environment providing resources and services to implement interdisciplinary projects in the course of studies on the efficiency of education. A combination of modern methods of pedagogical studies was applied to address the set problems. The authors used theoretical methods, such as analysis, generalisation, comparison, synthesis, and systematisation of research literature and teaching aids providing visibility in terms of the current outlook of the analysed problem and developing and introducing a hybrid cloud-based learning environment to support interdisciplinary projects. The authors also used empirical methods, such as pedagogical experiments, to determine the impact of digital services in the hybrid cloud-based learning environment on students' performance in each discipline of interdisciplinary projects and their profiles in the course of the project. For numeric processing of research findings and statistical tests for objectivity, the authors used methods of mathematical statistics. The case is made for using cloud computing in the education of future professionals. Experimental analysis is conducted to determine the impact of the hybrid cloud-based learning environment providing resources and services to implement interdisciplinary projects in the course
\end{abstract}


of studies on the efficiency of education. The positive impact is shown for the hybrid cloud-based learning in terms of students' progress. The results can make the basis for developing and introducing a hybrid cloud-based learning environment to support interdisciplinary projects. The scientific novelty of this study is underscored by the analysis of the impact of digital services of the hybrid cloud-based learning environment on the efficiency of educating future professionals in the course of an interdisciplinary project.

Keywords: Cloud computing. Cloud services. Project-based education. Interdisciplinary project. Students. Professional competence.

\section{RESUMO}

Mirar. Este artigo tem como objetivo analisar o impacto do ambiente híbrido de aprendizagem baseado em nuvem, fornecendo recursos e serviços para a implementação de projetos interdisciplinares no curso de estudos sobre a eficiência da educação. Métodos Uma combinação de métodos modernos de estudos pedagógicos foi aplicada para resolver os problemas definidos. Os autores usaram métodos teóricos, como análise, generalização, comparação, síntese e sistematização da literatura de pesquisa e auxiliares de ensino, proporcionando visibilidade em termos da perspectiva atual do problema analisado e desenvolvendo e introduzindo um ambiente de aprendizagem baseado em nuvem híbrido para apoiar a interdisciplinaridade projetos. Os autores também usaram métodos empíricos, como experimentos pedagógicos, para determinar o impacto dos serviços digitais no ambiente de aprendizagem baseado em nuvem híbrida sobre o desempenho dos alunos em cada disciplina de projetos interdisciplinares e seus perfis no decorrer do projeto. Para processamento numérico de resultados de pesquisas e testes estatísticos de objetividade, os autores usaram métodos de estatística matemática. Principais resultados $\mathrm{O}$ case é feito para o uso da computação em nuvem na formação de futuros profissionais. A análise experimental é conduzida para determinar o impacto do ambiente de aprendizagem baseado em nuvem híbrida, fornecendo recursos e serviços para implementar projetos interdisciplinares no curso de estudos sobre a eficiência da educação. O impacto positivo é mostrado para a aprendizagem baseada em nuvem híbrida em termos de progresso dos alunos. Aplicabilidade. Os resultados podem servir de base para o desenvolvimento e introdução de um ambiente de aprendizado híbrido baseado em nuvem para apoiar projetos interdisciplinares. A novidade científica deste estudo é reforçada pela análise do impacto dos serviços digitais do ambiente de aprendizagem baseado em nuvem híbrida sobre a eficiência da formação de futuros profissionais no curso de um projeto interdisciplinar.

Palavras-chave: Computação em nuvem. Serviços na nuvem. Educação baseada em projetos. Projeto interdisciplinar. Alunos. Competência profissional.

\section{RESUMEN}

Apuntar. Este artículo tiene como objetivo analizar el impacto del entorno de aprendizaje híbrido basado en la nube, proporcionando recursos y servicios para implementar proyectos interdisciplinarios en el curso de estudios sobre la eficiencia de la educación. Métodos Se aplicó una combinación de métodos modernos de estudios pedagógicos para abordar los problemas planteados. Los autores utilizaron métodos teóricos, como el análisis, la generalización, la comparación, la síntesis y la sistematización de la literatura de investigación y las ayudas didácticas, proporcionando visibilidad en términos de la perspectiva actual del problema analizado y desarrollando e introduciendo un entorno de aprendizaje híbrido basado en la nube para apoyar la interdisciplinariedad proyectos. Los autores también utilizaron métodos empíricos, como experimentos pedagógicos, para determinar el impacto de los servicios digitales en el entorno de aprendizaje híbrido basado en la nube en el desempeño de los estudiantes en cada disciplina de proyectos interdisciplinarios y sus perfiles en el transcurso del proyecto. Para el procesamiento 
numérico de los resultados de la investigación y las pruebas estadísticas de objetividad, los autores utilizaron métodos de estadística matemática. Resultados principales Se argumenta a favor del uso de la computación en nube en la formación de futuros profesionales. Se realiza un análisis experimental para determinar el impacto del entorno de aprendizaje híbrido basado en la nube que proporciona recursos y servicios para implementar proyectos interdisciplinarios en el curso de estudios sobre la eficiencia de la educación. El impacto positivo se muestra para el aprendizaje basado en la nube híbrida en términos de progreso de los estudiantes. Aplicabilidad. Los resultados pueden sentar las bases para desarrollar e introducir un entorno de aprendizaje híbrido basado en la nube para apoyar proyectos interdisciplinarios. La novedad científica de este estudio se ve subrayada por el análisis del impacto de los servicios digitales del entorno de aprendizaje híbrido en la nube sobre la eficiencia de la formación de futuros profesionales en el transcurso de un proyecto interdisciplinario.

Palabras clave: Computación en la nube. Servicios en la nube. Educación basada en proyectos. Proyecto interdisciplinario. Estudiantes. Competencia profesional.

\section{INTRODUCTION}

The advance of science and technology and the development of the information society create the need for not only reshaping the content of higher education but also making sure the education system rapidly adapts to any changes (Lyakhova et al., 2020; Silaeva et al., 2020). The resource-based economy gives way to the new economy driven by the development of the creative industry, new information technology, and business processes supporting leadership and competitiveness at the national level (Krivova et al., 2020; Anufrieva et al., 2020). Education is a key driver of economic growth. Thus, the new economy poses new requirements for educating future professionals and realising their intellectual potential. This entails the need to implement information and communications technology (ICT) in the educational process (Milovanova et al., 2020; Golubeva et al., 2020).

In 2000, the international project TUNING (Tuning Educational Structures in Europe) was launched in Europe as a framework for refining education under the Bologna Process. The project defines 30 generic competences (instrumental, interpersonal, and systemic) shaping the general profile of studies in a modern higher education institution (HEI). This includes the two critical highlights, such as the "ability to organise and plan" and the "ability to work independently" (Donà dalle Rose \& Haug, 2013). These competences are directly developed in, and make the outcomes of, a properly organised educational process.

This is made possible by the engagement of IT in the education process and the actualisation of project-based learning activities of students (Gogiberidze et al., 2020; Melnikova et al., 2019). In the modern context, it is impossible to imagine education or professional training for the youth without independent studies, given the constant growth of educational input, the changed educational paradigm, and the enhancement of IT in nearly all practical fields.

Graduates today need to master both professional competences and soft skills. Employers expect that the new generation of professionals will master dozens of such skills, including creative thinking, time management, communication and networking skills, project management, and efficient teamwork.

For future professionals to hold leadership in their fields and be able to meet the requirements of their customers, one should focus on specialist and complex problem-solving abilities, as well as the abilities to adopt modern decision-making techniques and methods facilitating teamwork. This means the educational process should focus on the development of integral competence including not only professional competences but also soft skills (Majid et al., 2012). The problem with such integral competence consists in the fact that students only get a complex assignment during the preparation of a graduation project. For this study, integral 
competence in a future professional describes the ability to apply specialist and complex problemsolving skills and perform on practical goals in complex and uncertain contexts. The structure of integral competence of a future professional here refers to the composition of professional and generic competences making up the attainment of such competence.

One of the most efficient ways for developing such integral competence is through students' project-based activities focusing on complex problem-solving. Such complex problems can be developed as interdisciplinary projects but facilitated by the online environment of collaboration in the course of the project task.

Project-based learning should engage tools to stimulate and maintain motivation in students and facilitate easy access to learning resources and information inputs. Efficient project-based studies should not be limited to the use of specific IT but require the development of a whole system of information and methodological support guided by the learner-centred paradigm.

Our research centred on the hypothesis that the hybrid cloud-based computing environment creates a positive impact on students' progress.

The findings suggest that the research objective is met.

\section{LITERATURE REVIEW}

Project-based engagements are one of the stages of the educational process. They focus on the development of skills for the digital environment, as well as professional self-development, creativity, information culture, and independent work aimed at the enhancement and systematisation of professionally relevant skills and capabilities (Maida, 2011). Teachers and, potentially, employers should provide guidance and support while empowering students to largely own project planning, implementation, and analysis (Szállassy, 2008).

T. Roberts, J. Harlin (2007), D. Klein (2002) and R.T. Howell (2003) discussed the organisation of team project work for future professionals in a single discipline. As a rule, the project-based method is used for teaching a specific discipline. This single-discipline approach limits the use of the project-based methodology. Integrating several academic disciplines remains a problem that needs to be solved in the development of project assignments to enhance knowledge acquisition in general and in each discipline to build students' integral competence.

Interdisciplinary projects can provide a relevant tool for competence-based education (Aznar et al., 2015; Gestwicki \& McNely, 2016; Polutnik et al., 2013).

Interdisciplinary projects can be organised to familiarise students with professional realities and promote active teamwork. They provide visibility into different fields of their specialisation and help to ensure stronger interest in the profession (Barak \& Dori, 2005; Biasutti \& El-Deghaidy, 2014).

This interdisciplinary approach engages knowledge from different scientific areas to solve the problem. The use of this interdisciplinary approach in educating future professionals is a constituent part of the development of their professional competence (Butler \& Christofili, 2014). Interdisciplinary projects make an important component in the development of students' competence (Johnson \& Delawsky, 2013).

Students' working environment arrangements are guided by the need to set up group work on projects and facilitate practical application of acquired knowledge and developing teamwork and communication skills (Meirink et al., 2010).

Studying and substantiating the relevant applications of ICT in education should be viewed as one of the most important pedagogical problems, specifically in the context of humanisation of education (Mohammadi, 2015).

Alongside the concept of modernisation of education, the issue of a single learning environment facilitated by the active use of high-speed ICT is widely discussed by scholars, faculty, and curriculum developers. A way for such a learning environment to exist, apart from the active 
development of educational online resources and technologies, is the adoption of cloud computing in education (Sasikala \& Prema, 2010; Sabi et al., 2016; Thomas, 2011).

The application of cloud computing in education is addressed by numerous researchers (Kaur \& Sawtantar, 2015; Ganesh et al., 2012; Okai et al., 2014). The use of cloud computing in education provides for stronger theoretical and practical competence of future professionals (Boja et al., 2013; Mircea, 2010; Sommerville, 2013).

Infusing the learning process with modern ICT tools, specifically cloud services, creates a close relation between specific trends in IT and the methodological systems via their impact on technology subsystems (Al-Zoube et al., 2010). Apart from their considerable influence on the means of education, cloud technologies also influence other components of the technological subsystem in methodology, specifically the methods and forms of learning.

N. Sclater (2010) believes cloud computing practices serve as an indication to revise the methodological system of studies in favour of a bigger share of group and activity-based forms of engagements, stronger student independence in knowledge and skill acquisition, and technological integration between class and out-of-class engagements involving blended learning.

According to researchers (Alamri \& Qureshi, 2015; Elamir et al., 2013), the adoption of cloudoriented learning tools in education, specifically in $\mathrm{HEI}$, provides the following additional opportunities:

- potential cost savings: transition to the cloud usually implies a departure from the CAPEX model (tangible assets subject to devaluation) toward the OPEX model (fees);

- collaboration: includes a wide range of communication tools and provides an ideal solution for online classes or peer-to-peer support or learning;

- backup: an important function of cloud computing is automated saving of contents which means no relevant files would be lost or deleted;

- accessibility: all data stored in the cloud are easily accessible on any device, including mobile phones or tablets;

- storage: nearly all types of content can be stored in the cloud, including music, files, ebooks, applications, photos, and so on;

- flexibility: fast shifts in the software requirements posed for today's and tomorrow's students;

- no requirements for own expertise: network administrators can save significant time by eliminating routine current tasks.

Leading vendors of cloud technologies have acknowledged the importance of adjusting their services specifically to meet the needs of educational institutions. They integrate specialist software in bundles at low prices to ensure more institutions can afford them (Sabi et al., 2016).

V.H. Pardeshia (2014) considers the selection criteria for cloud-based learning systems, specifically, in the basics of computer science. The author offers some guidance on selecting such systems as follows:

- design (reliability, accessibility, safety, adaptivity, ease of use and administration, zero cost),

- technology (access control supporting multiple levels of access, cloud-based data storage, integration with other cloud-based services, capability to upload multiple file formats),

- communication (user registration, communications between registered users, creation of groups, forums, chats),

- information and didactic level (structure, calendar, student progress reviews, file sharing options, tests and polls, group and individual work arrangements, analytics on specific courses).

T. Ercan (2010) believes cloud technologies contribute to a better quality of learning among $\mathrm{HEI}$ students and a stronger connection between teachers and students. To build a cloud-based 
learning system, consider using a university's private cloud storage for uploading an online learning resource integrating theoretical and applied contents.

Based on a review of studies on the use of cloud technologies in education (Tomasz \& Bajdor, 2015; Odeh et al., 2017; Ozdamlia \& Bicen, 2014; Mansuri et al., 2014), this technological integration into the information and methodological support of independent learning serves the following main directions: expansion of education quality management; opening-up of the potential to select individual learning trajectories; using cloud technologies to support the convergence of education with students' information environment and convergence of education and real professional experience.

K. Yadav (2014) analyses the problems of cloud applications in education and develops a taxonomy of the cloud for different types of students' learning activities.

The list of cloud services applicable in education is extensive. At the user level (faculty and students), the main advantage consists in cross-platform accessibility, availability of mobile applications, and ease of use and registration. The application of cloud services for education is also a topic of many studies. T. Guasch, I. Alvarez, and A. Espasa (2010) models an e-environment supported by Microsoft SharePoint and proposes a methodology for arranging students' group project work using cloud services of Office 365. J. Ravitz and J. Blazevski (2014) describe the experience of using Microsoft Office 365 services for students' group work with a focus on balancing social and academic learning. The researchers draw attention to engaging students in designing portals in SharePoint.

T.M. Morales, E. Bang, and T. Andre (2013) address the concept of collaboration in peer-topeer content exchange with feedback using Microsoft SharePoint. This helps the teacher build students' awareness of the role of collaboration. F. Koch et al. (2016) consider the arrangements of project-based group work of future IT professionals with cloud services of Microsoft and Google.

C. Bulla et al. (2016) conclude that the most common way to use cloud technologies is the "software as a service" model. They specifically point at Microsoft Teams enabling students to conduct and discuss team projects, publish the outcomes online for further analysis, and consolidate tables and diagrams and effect tests and self-control of learning progress.

\section{METHODS}

Considering the purpose of this study and the literature review, the following research problems are set in this paper:

1. To develop the stages of implementation of the project titled "Business Project Development for an IT Company," the composition of each stage, assessment criteria, and expected outcomes.

2. To determine the impact of digital services in a hybrid cloud-based learning environment on students' performance in each discipline of the interdisciplinary project.

3. To determine the impact of digital services of a hybrid cloud-based learning environment on students' professional competences and their profiles in the course of the interdisciplinary project.

Two samples of students were selected to run the experiment. The control group (condition 1, 40 people) conducted an interdisciplinary project without the use of cloud services. The experimental group (condition 2, 46 people) were invited to operate in an organised environment in the cloud service Microsoft Teams. To evaluate the contribution of each team member in the aggregate project outcome, an additional survey was developed so that students would assign points to everyone on their own.

Find an assessment of students' academic progress and outcomes of the interdisciplinary project in Table 1. 
Table 1. Points assigned for each type of activity.

\begin{tabular}{lc}
\hline \multicolumn{1}{c}{ Criterion } & Maximum \\
\hline Exam (pass-fail exam) in Systems Analysis & 15 \\
Exam (pass-fail exam) in Computer Networks & 15 \\
Exam (pass-fail exam) in Web Technology and Web Design & 15 \\
Exam (pass-fail exam) in Economics and Business & 15 \\
Project report & 20 \\
Assessment of individual contributions in the aggregate project outcomes & 20 \\
\hline Total & 100
\end{tabular}

Three levels of digital competence (low, medium, and high) were determined based on the results of the interdisciplinary project. The overview of the components and attainment levels of digital competence is provided in Table 2.

Table 2. Digital competence attainment levels.

\begin{tabular}{|c|c|c|}
\hline $\begin{array}{l}\text { Elements of digital } \\
\text { competence }\end{array}$ & Level & Student's general competence profile \\
\hline \multirow{3}{*}{$\begin{array}{l}\text { Ability to strategically } \\
\text { adopt technologies in } \\
\text { accordance with learning } \\
\text { objectives }\end{array}$} & Low & The students can partially choose tools. \\
\hline & Medium & $\begin{array}{l}\text { The student chooses ICT tools with the support of a teacher and } \\
\text { strategically adopts them in accordance with the learning objectives. }\end{array}$ \\
\hline & High & $\begin{array}{l}\text { The student independently chooses ICT tools and strategically adopts } \\
\text { them in accordance with their learning objectives. }\end{array}$ \\
\hline \multirow{3}{*}{$\begin{array}{l}\text { Use of digital tools for data } \\
\text { analysis and } \\
\text { representation in a variety } \\
\text { of forms }\end{array}$} & Low & The student is familiar with data analysis tools but rarely engages them. \\
\hline & Medium & $\begin{array}{l}\text { The student is skilled in the use of digital tools for data analysis and } \\
\text { representation but only engages them when urgently required. }\end{array}$ \\
\hline & High & $\begin{array}{l}\text { The student is skilled in the use of tools and rendering various data } \\
\text { representations as may be needed. }\end{array}$ \\
\hline \multirow[t]{3}{*}{$\begin{array}{l}\text { Ability to use digital tools } \\
\text { to arrange teamwork }\end{array}$} & Low & $\begin{array}{l}\text { The student is getting into the basics of tools for teamwork and would } \\
\text { not engage them consistently apart from occasional uses. }\end{array}$ \\
\hline & Medium & $\begin{array}{l}\text { The student is getting into the basics of tools for teamwork and engages } \\
\text { them not only independently but also to arrange teamwork. }\end{array}$ \\
\hline & High & $\begin{array}{l}\text { The student is getting into the specifics of tools for teamwork and actively } \\
\text { engages them not only independently but also to arrange teamwork. }\end{array}$ \\
\hline \multirow[t]{3}{*}{$\begin{array}{l}\text { Ability to choose and use } \\
\text { planning and project } \\
\text { management tools }\end{array}$} & Low & $\begin{array}{l}\text { The student engages planning and project management tools as } \\
\text { recommended by the teacher and proceeds to adopt new services as may } \\
\text { be needed and with the help of the teacher. }\end{array}$ \\
\hline & Medium & $\begin{array}{l}\text { The student chooses tools independently as required but proceeds to } \\
\text { adopt new services with the help of the teacher. }\end{array}$ \\
\hline & High & $\begin{array}{l}\text { The student chooses tools independently as required and is skilled } \\
\text { enough to use new services independently. }\end{array}$ \\
\hline
\end{tabular}

In each group, students were also invited to complete a survey and independently assess their professional and personal progress in the course of the project on a scale of 10.

\section{RESULTS}


Upon completion of the interdisciplinary project, students' academic progress was meant to be assessed in each of the disciplines involved on a scale of 100.

The average assessment of each group is charted in Figure 1.

Figure 1. Students' average assessment in each of the disciplines in the control and experimental groups.

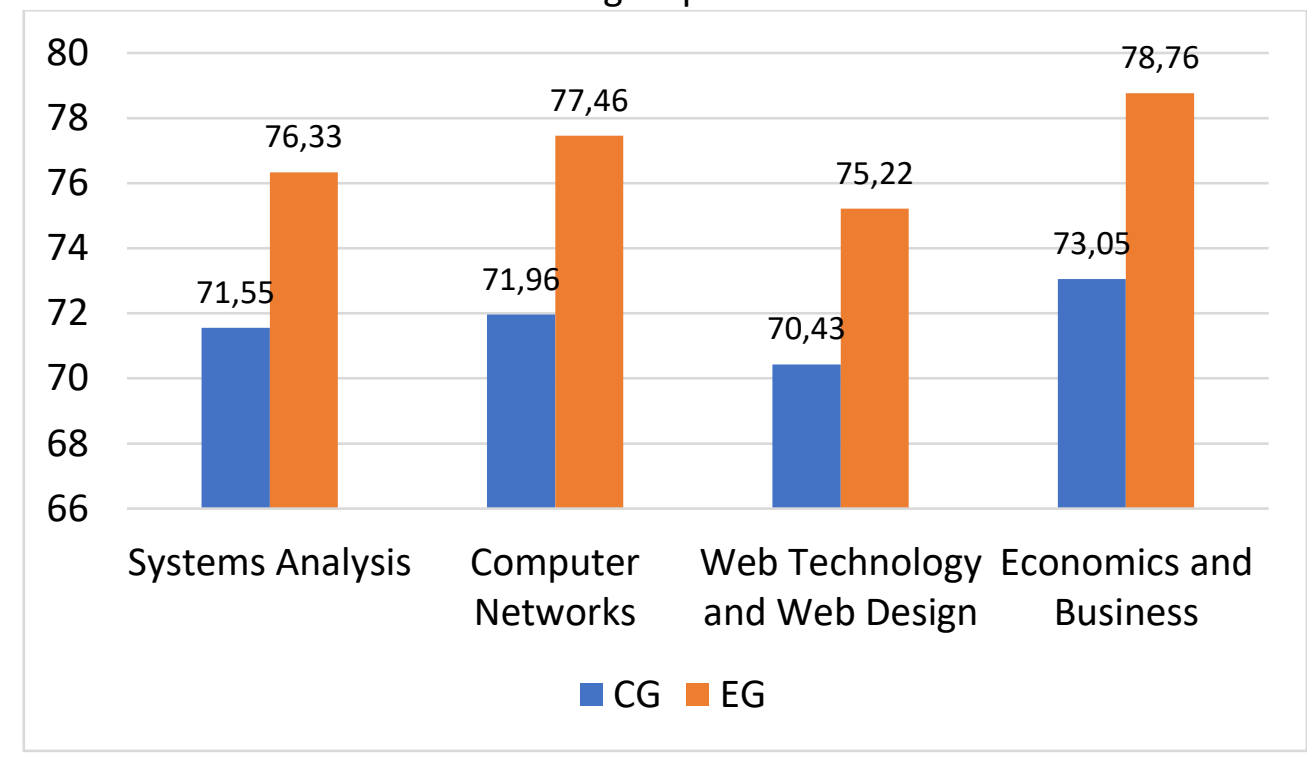

Apart from the assessment of the average efficiency in using the hybrid cloud-based learning environment to implement interdisciplinary projects, additional indicators were used for guidance in terms of digital competence levels: ability to strategically adopt technologies in accordance with learning objectives; ability to use digital tools for data analysis and representation in a variety of forms; ability to use digital tools to arrange teamwork; ability to choose and use planning and project management tools.

Table 3 shows digital competence attainment levels in the experimental and control groups.

Table 3. Digital competence attainment levels in the experimental and control groups.

\begin{tabular}{|c|c|c|c|c|c|c|}
\hline \multirow[t]{2}{*}{ Skill } & \multicolumn{3}{|c|}{ CG } & \multicolumn{3}{|c|}{$\mathrm{EG}$} \\
\hline & Low & Medium & High & Low & Medium & High \\
\hline $\begin{array}{l}\text { strategically adopting } \\
\text { technologies in accordance } \\
\text { with learning objectives }\end{array}$ & 30.0 & 42.5 & 27.5 & 21.74 & 32.61 & 45.65 \\
\hline $\begin{array}{l}\text { using digital tools for data } \\
\text { analysis and representation } \\
\text { in a variety of forms }\end{array}$ & 27.5 & 47.5 & 25.0 & 19.57 & 39.13 & 41.30 \\
\hline $\begin{array}{l}\text { using digital tools to } \\
\text { arrange teamwork }\end{array}$ & 40.0 & 35.0 & 25.0 & 21.74 & 30.43 & 47.83 \\
\hline $\begin{array}{l}\text { choosing and using digital } \\
\text { tools for planning and } \\
\text { project management }\end{array}$ & 42.5 & 37.5 & 20.0 & 17.39 & 30.43 & 52.17 \\
\hline
\end{tabular}

As can be seen from Table 2, more than $80 \%$ of students in the experimental group demonstrated high or medium digital competence levels vs. only $60-70 \%$ in the same bracket in the control group.

Surveys were used to look into the progress in students' professional and personal profiles in the course of the project (Figures 2 and 3 ). 
Figure 2. Students' professional competence levels in the course of interdisciplinary project implementation.

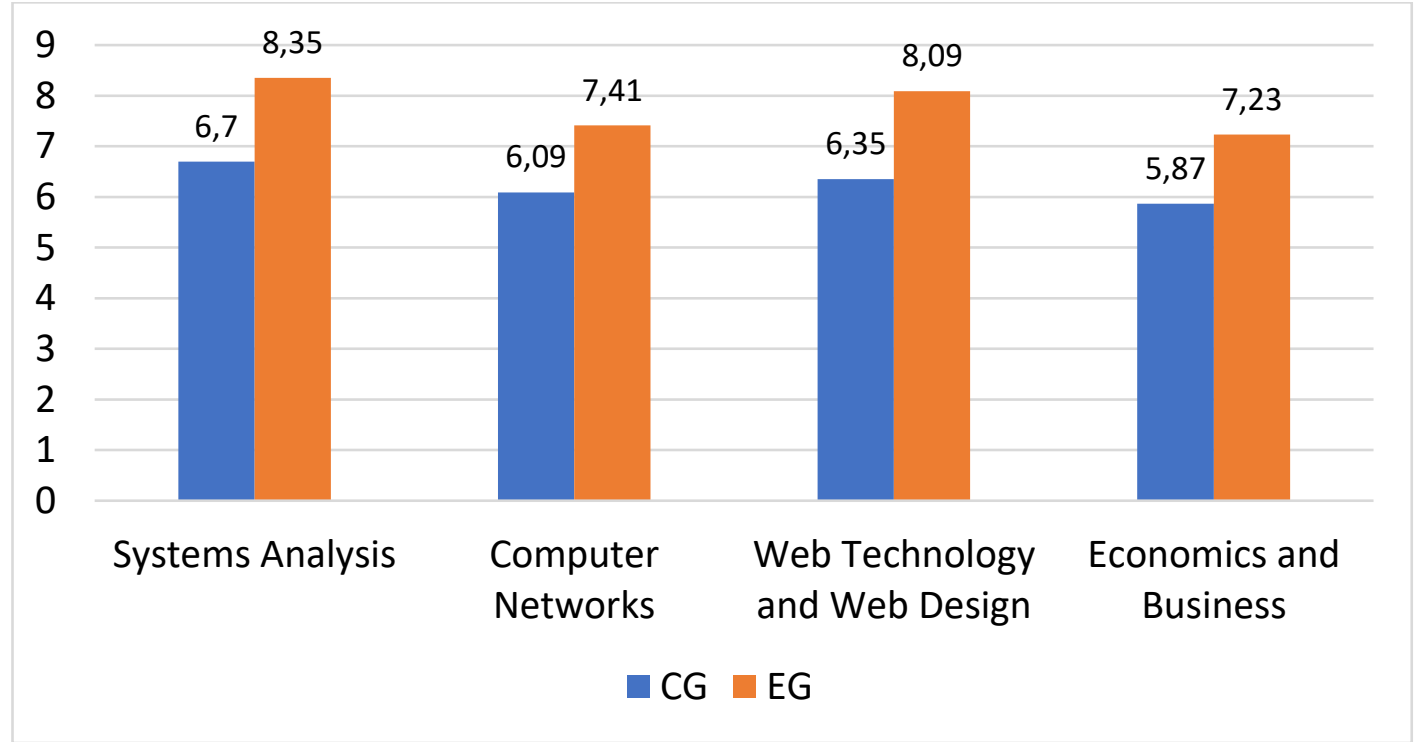

In the assessment of professional competence development, the experimental group showed a stronger professional competence profile vs. the control group: up by $24.71 \%$ in Systems Analysis; by $21.74 \%$ in Computer Networks; by $27.45 \%$ in Web Technology and Web Design; by 23.18\% in Economics and Business.

Figure 3. Students' personal competence levels in the course of interdisciplinary project implementation.

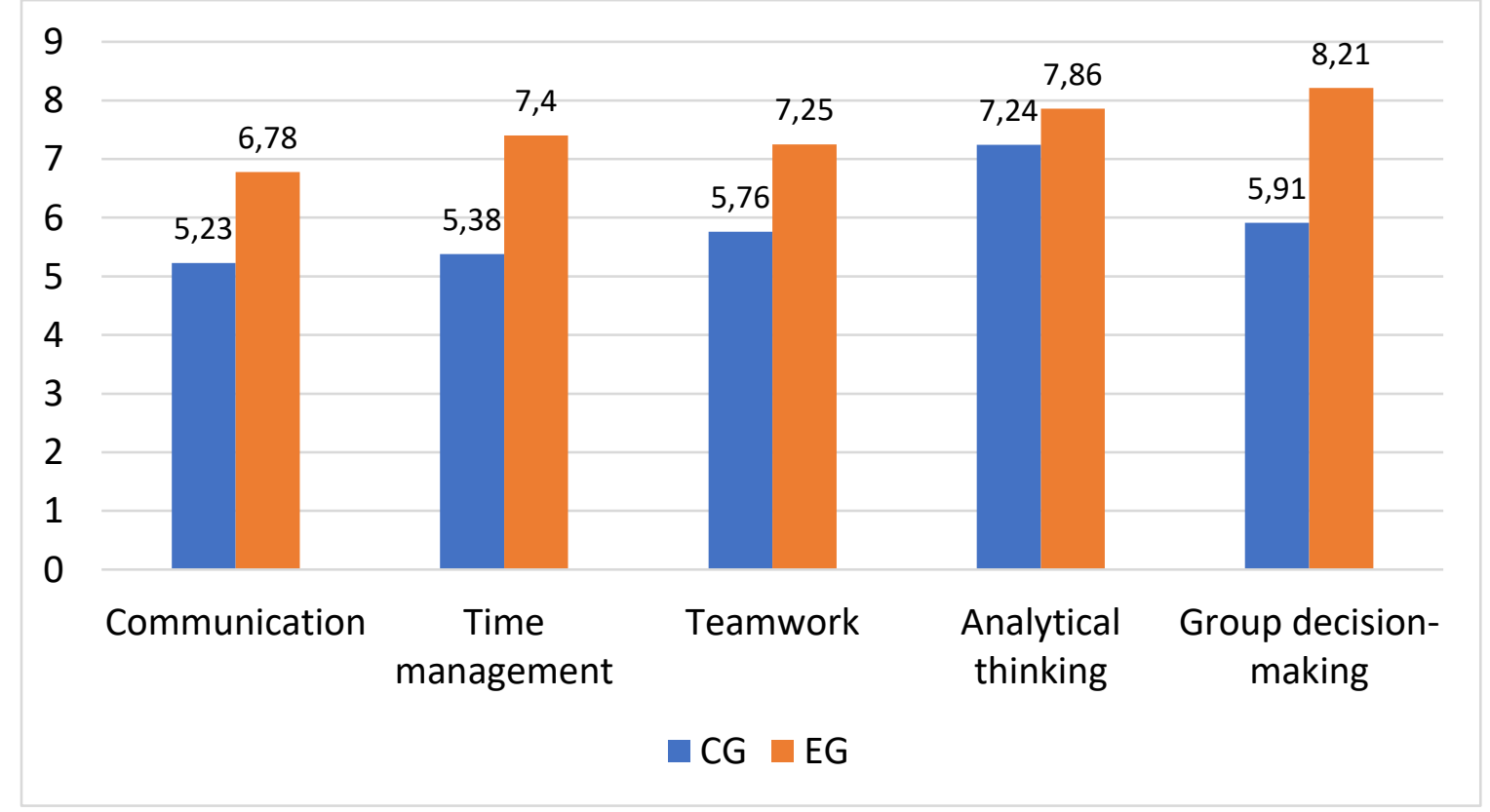

In the assessment of professional competence development, the experimental group showed stronger development in the following skills (increase vs. the control group): communication skills by $29.64 \%$; time management by $37.55 \%$; teamwork by $25.87 \%$; analytical thinking by $8.57 \%$; group decision-making by $38.92 \%$. 
Moreover, the experimental group pointed at the following advantages of the hybrid cloudbased learning environment in the implementation of an interdisciplinary project:

ease of access to all required resources;

convenience of team communications;

access to the external environment at any time and on any device;

possibility to share tasks.

To assess the accuracy and relevance of the results, we calculated students' average grades in four academic disciplines involved in the project and proposed a hypothesis that the obtained results are significant and not random. Accordingly, two independent distribution series were rendered.

To assess the series, a descriptive statistic is calculated in Table 4.

Table 4. Descriptive statistic.

\begin{tabular}{ccccccc}
\hline Group & $\begin{array}{c}\text { Number of } \\
\text { students }\end{array}$ & $\begin{array}{c}\text { Average } \\
\text { grade }\end{array}$ & $\begin{array}{c}\text { Standard } \\
\text { deviation }\end{array}$ & $\begin{array}{c}\text { Coefficient of } \\
\text { variation }\end{array}$ & $\begin{array}{c}\text { Coefficient of } \\
\text { skewness }\end{array}$ & Excess kurtosis \\
\hline CG & 40 & 72 & 8.833 & $12.31 \%$ & 0.439 & -0.88 \\
EG & 46 & 77 & 9.879 & $12.84 \%$ & 0.19 & -1.27 \\
\hline
\end{tabular}

The coefficients of variation in the two distribution series are below $30 \%$, i. e., the population is homogeneous and the results are reliable.

Student's t-test is used to test the hypothesis that the means of two populations are equal to prove the significance of the results. This test requires the normality of data. To test it, the coefficients of skewness and kurtosis were calculated. Given that these levels are not substantially different from zero, sample data distribution can be considered close to normal.

The resulting calculations for the experiments render the level of the t-test equal to 2.531 . The corresponding critical value of the t-test for 84 degrees of freedom and significance level $\alpha=$ 0.05 equals 1.96. The $t$-value calculated for the experimental data is greater than the critical value: 2.531> 1.96. Therefore, we reject the null hypothesis that the means of two populations are equal which would imply there is no relationship with the analysed factor.

Accordingly, the conducted analysis suggests that using the hybrid cloud-based learning environment does have an impact on students' progress.

\section{DISCUSSION}

In this study, the hybrid cloud-based learning environment is understood as an ICT environment employing the cloud computing technology and integrating didactically relevant educational content and services of an institution's academic cloud with public clouds (Sultan, 2010; Salam \& Sardar, 2015).

Building and running project implementation in an interdisciplinary environment means that faculty can choose from available means to perform project tasks, integrate professional tools as may be necessary, and maintain communications between the teachers of the project discipline and student groups. Students can efficiently plan project stages, assign tasks among team members, track progress, and arrange teamwork to produce the final product.

In accordance with (Lin \& Chen, 2012; Bouyer \& Arasteh, 2014; Kaur \& Sawtantar, 2015), we identify competence-based, communication, and technology components as the structural components of a university-owned hybrid cloud-based learning environment which may be used in the implementation of interdisciplinary projects.

The competence-based component determines competences required for arranging an interdisciplinary project. Where students are concerned, these specifically include digital, professional, and personal competences, such as teamwork, communication, time management, 
analytical thinking, and group decision-making. Integral competence is shaped by practicing a complex approach to designing and solving a project task, which integrates professional competences, from systems analysis to network technologies to web technologies and business planning. Teachers need digital competence and the ability to facilitate group work, apply projectbased learning methods, and engage ICT in the course of studies. Administrators' requisite competences include the ability to administer resources, services, and users in the cloud-based environment (Robertson, 2013).

The developed model served as the basis for creating the cloud-based environment for team projects in Microsoft Teams integrating all necessary services (communication and technology components) to implement an interdisciplinary project.

This environment facilitated interaction between teachers and groups. The software component comprises communication tools, project management tools, and tools for uploading and storing learning resources integrated into Microsoft Teams and complemented by additional compatible tools. Microsoft Teams created an environment for each team, providing students access to learning resources (Class Notebook, OneDrive), communication tools (Tasks, Chat), and project management tools (Meetings, Planner). Students had the opportunity to integrate additional services and tools, such as communication tools (Outlook, Skype), professional tools (Visio, Microsoft Excel, PHP, MySQL, Packet Tracer), and tools for rendering project progress and outcomes (Forms, Sway). Teachers can integrate additional required learning aids when necessary (online courses, webinars).

The use of a hybrid cloud-based learning environment to facilitate student work on an interdisciplinary project contributes to the development of not only professional competences but also soft skills (Shek et al., 2017; Cornalli, 2018).

The technology component governs the content, methods, and forms of learning in the course of the project. The implementation of the interdisciplinary project titled "Business Project Development for an IT Company" engaged a variety of tools stated in the technology and software components of the hybrid cloud-based learning environment.

This project aimed to develop students' integral competence, as well as digital, professional, and personal competence.

Students were tasked with developing an IT business project. The project composition is described as follows: to conduct marketing research in IT services; to complete structure-function analysis and object-based analysis of the subject area; to model the business process; to design a computer network for the corporate office and choose the required equipment; to build a website to promote corporate activities; to develop a business plan for the company; to figure out the payback period and company strategy.

Figure 4 lays out the stages of project implementation, the composition of each stage, assessment criteria, and expected outcomes. Guidance and all necessary learning resources were provided for each task in an online study guide. Teachers chose tools for each stage of the project.

Figure 4. Stages of implementation of the project titled "Business Project Development for an IT Company".

Title: "Business Project Development for an IT Company"

\begin{tabular}{|l|l|}
\hline \multicolumn{1}{|c|}{ Composition of tasks (stages): } & \multicolumn{1}{|c|}{ IT: } \\
\hline 1. Marketing research in IT services; choosing the company's & Microsoft Visio, Erwin Data \\
focus. Software and hardware development for the system \\
of structure-function analysis and object-based analysis. \\
Structure of information application. System architecture.
\end{tabular}




\begin{tabular}{|l|l|}
\hline $\begin{array}{l}\text { 2. Corporate IT infrastructure. Network architecture, } \\
\text { software and hardware installation. Computer network } \\
\text { design. Network equipment specification. }\end{array}$ & Cisco Packet Tracer \\
\hline $\begin{array}{l}\text { 3. Website development. Integration with the corporate } \\
\text { administrative information system. }\end{array}$ & $\begin{array}{l}\text { PHP, CSS JavaScript HTML, } \\
\text { MySQL }\end{array}$ \\
\hline $\begin{array}{l}\text { 4. Company business plan. Development strategy. Legal } \\
\text { aspects. }\end{array}$ & Business constructor \\
\hline
\end{tabular}

Project assessment criteria: size and scope, design, implementation efficiency, individualisation, originality (creativity), decision-making rationale

Outcome: business project development for an IT company

The composition of the interdisciplinary project guided the choice of learning methods and forms, both traditional and cloud-based. Traditional forms and methods were used for theoretical studies and practical work on the disciplines in the project. Specifically, the blended learning method was used for practicing the theoretical input with online resources during independent work. Class hours were dedicated to practical work. Cloud-based learning methods were used for communication and collaboration on project tasks in Microsoft Teams and integrated services of Outlook and Skype.

To facilitate students' work on the project, the project stage included the development of the project schedule and assignment of project days for specific tasks. The theoretical input required for addressing the set tasks was provided in lectures in each of the disciplines according to a timetable. E. g., the first stage of the project included four weeks of theory in Systems Analysis and practicing theoretical knowledge in line with chapters of the online course followed by work on project tasks on the respective project day.

Teachers used the integrated task service to supply tasks to students for each project date, specifying the deadlines and providing additional resources and guidance for the tasks.

Accordingly, we integrated the project-based and blended learning methods when students worked independently with theoretical resources, performed practical tasks, and spent class hours working on project tasks.

Project work in the cloud-based environment built around Microsoft Teams required communication between teachers; between teachers and teams; students in a team; teachers and administrators.

E. g., Class Notebook was used to upload learning resources for group work. Groups analysed the assessment criteria for each stage of the project, expected outcomes, and schedule. Team members had this common ground for collaboration where they engaged in group work to address project goals, and each member had resources for independent work.

Teachers had the opportunity to upload additional learning resources, while students could share useful input for project tasks, create files, and jointly edit them in the cloud storage OneDrive.

Chats were used for communication in teams in the course of project work and obtaining updates from the team (new tasks, files uploaded to the repository, new tabs added in the team environment).

Conferences helped students to facilitate meetings (conferences) to work on the project.

With Planner, teams designated tasks at different project stages, set deadlines, assigned responsibility, and tracked each other's progress on tasks. While working on the project in the cloudbased environment, students had the opportunity to customise it to meet their team's needs and integrate professional tools as required for project tasks. 


\title{
CONCLUSION
}

Today's educational institutions appreciate the effectiveness of cloud computing for facilitating and administering the learning process. By using various models of cloud computing and acquiring infrastructure services, platforms, or software, education institutions can cut costs and improve the efficiency of learning and store, process, and analyse data. This provides advantages for $\mathrm{HEl}$ as permanent access to various collaboration environments and important applications requires a minimum investment in equipment and cloud software.

Cloud technologies have an impact on group forms of learning, as they facilitate easier collaboration and expand communication capabilities. The use of cloud technologies fosters innovative thinking in terms of learning methodologies, project-based methods, flipped classroom, and blended learning techniques.

The functional capabilities of the cloud environment including services for planning, communication, and collaboration, as well as resources for informal education and tools for assessments and reflection, provide an impact on the efficiency of learning and development of professional and personal skills. Accordingly, by influencing the means, methods, and forms of learning, cloud technologies create an impact on the wider methodological system of learning.

The cloud-based environment of Microsoft Teams facilitates tasks in the fields of communication, learning, and project management. It enables the integration of additional tools for interdisciplinary projects, specifically professional, educational, and other. It also creates an effective environment for developing digital, professional, and personal competences of future professionals. Also, interdisciplinary projects help to develop the integral competence of future professionals.

This environment should be designed to meet requirements in terms of technology, communication, and competence-based components. They should be aligned together and focused on the attainment of goals in the interdisciplinary project in line with the set composition, methods, and forms of learning.

As a result of the implementation of the interdisciplinary project in this environment, the level of students' academic performance increases, on average, by $7.27 \%$. The increase in the attainment of digital, professional, and personal competences ranges from $15 \%$ to $38 \%$.

Therefore, the hypothesis is confirmed that the use of the hybrid cloud-based learning environment creates a positive impact on students' progress.

Further research could focus on the analysis of the impact of the proposed learning technology on the development of integral competence, as well as respective measures to assess it.

\begin{abstract}
Authors' Contributions: Natalia Kovalevskaia: conception and design, acquisition of data, analysis and interpretation of data, drafting the article, critical review of important intellectual content. Emma Nikolaevna Gilyazeva: conception and design, acquisition of data, analysis and interpretation of data, drafting the article, critical review of important intellectual content. Olga Fedorovna Lobazova: conception and design, acquisition of data, analysis and interpretation of data, drafting the article, critical review of important intellectual content. Irina Albertovna Duborkina: conception and design, acquisition of data, analysis and interpretation of data, drafting the article, critical review of important intellectual content. Antonina Pavlovna Sokolova: conception and design, acquisition of data, analysis and interpretation of data, drafting the article, critical review of important intellectual content. All authors have read and approved the final version of the manuscript.
\end{abstract}

Ethics Approval: Not applicable.

Acknowledgments: Not applicable.

REFERENCES 
Al-Zoube, M., Abou El-Seoud, S., \& Wyne, M. F. (2010). Cloud computing based e-learning system. International Journal of Distance Education Technologies, 8(2), 58-71. https://doi.org/10.4018/idet.2010040105

Alamri, B. H., \& Qureshi, M. R. J. (2015). Usability of Cloud Computing to Improve Higher Education. International Journal Information Technology and Computer Science, 9, 59-65. https://doi.org/10.5815/ijitcs.2015.09.09

Anufrieva, N. I., Volkov, L. V., Aralova, E. V., Kolomyts, O. G., \& Myagkova, E. V. (2020). Environmental Education: Nurturing of the Humanistic Orientation of a Personality. Universal Journal of Educational Research, 8(11), 5529 - 5535. https://doi.org/10.13189/ujer.2020.081156

Araujo, A., \& Silva, I. P. (2020). Maker culture and educational robotics in physics teaching: developing an automated traffic light in high school. Journal of Research and Knowledge Spreading, 1(1), e11654.

Aznar, M., Zacares, J., Lopez, J., Sanchez, R., Pastor, J., \& Llorca, J. (2015). Interdisciplinary robotics project for first-year engineering degree students. Journal of Technology and Science Education, 5(2), 151-165. https://doi.org/10.3926/jotse.152

Barak, M., \& Dori, Y. J. (2005). Enhancing undergraduate students' chemistry understanding through project-based learning in an IT environment. Science Education, 89(1), 117-139. https://doi.org/10.1002/sce.20027

Biasutti, M., \& El-Deghaidy, H. (2014). Interdisciplinary project-based learning: an online wiki experience in teacher education. Technology Pedagogy and Education, 24(3), 339-355. https://doi.org/10.1080/1475939x.2014.899510

Boja, C., Pocatilu, P., \& Toma, C. (2013). The economics of cloud computing on educational services. Procedia-Social and Behavioral Sciences, 93, 1050-1054. https://doi.org/10.1016/j.sbspro.2013.09.328

Bouyer, A., \& Arasteh, B. (2014). The Necessity Of Using Cloud Computing In Educational System. Procedia - Social and Behavioral Sciences, 143, 581-585. https://doi.org/10.1016/i.sbspro.2014.07.440

Bulla, C., Hunshal, B., \& Mehta, S. (2016). Adoption of Cloud Computing in Education System: A Survey. International Journal of Engineering Science and Computing, 6(6), 63-75.

Butler, A., \& Christofili, M. (2014). Project-based learning communities in developmental education: a case study of lessons learned. Community College Journal of Research and Practice, 38(7), 638-650. https://doi.org/10.1080/10668926.2012.710125

Cornalli, F. (2018). Training and developing soft skills in higher education. In: 4th International Conference on Higher Education Advances (HEAd'18), Universitat Polit’ecnica de Val’encia, Val’encia, pp. 961-967. https://doi.org/10.4995/HEAd18.2018.8127

Donà dalle Rose, L. F., \& Haug, G. (2013). Programme Profiles and the Reform of Higher Education in Europe: The Role of Tuning Europe. Tuning Journal for Higher Education, 1, 203-222. https://doi.org/10.18543/tjhe-1(1)-2013pp203-222

Elamir, A. M., Jailani, N., \& Bakar, M. A. (2013). Framework and Architecture for Programming Education Environment as a Cloud Computing Service. Procedia Technology, 11, 1299-1308. https://doi.org/10.1016/j.protcy.2013.12.328

Ercan, T. (2010). Effective use of cloud computing in educational institutions. Procedia Social and Behavioral Sciences, 2, 938-942. https://doi.org/10.1016/j.sbspro.2010.03.130

Ganesh, D., Dutta, C., \& Malaya, B. (2012). Role of Cloud Computing in Education. In: 2012 International Conference on Computing, Electronics and Electrical Technologies (ICCEET), Nagercoil, India, pp. 832-836. https://doi.org/10.1109/ICCEET.2012.6203884

Gestwicki, P., \& McNely, B. (2016). Interdisciplinary Projects in the Academic Studio. Journal ACM Transactions on Computing Education, 16(8), 1-24. https://doi.org/10.1145/2732157

Gogiberidze, G. M., Isakov, V. A., Ershova, T. V., \& Shulgina, O. V. (2020). Development of innovations in the educational environment: inclusive education and digital technologies. Revista Inclusiones, 7(Especial), 147-158.

Golubeva, T. I., Kokhanovskaya, I. I., Golovneva, E. V., Fatykhova, A. L., \& Terekhova, N. V. (2020). Social networks and education: the increase in student learning efficiency and the search for means of control. Revista Inclusiones, 7(Especial), 48-60.

Guasch, T., Alvarez, I., \& Espasa, A. (2010). University teacher competencies in a virtual teaching/learning environment: Analysis of a teacher experience. Teaching and Teacher Education, 26, 199-206. https://doi.org/10.1016/i.tate.2009.02.018

Howell, R. T. (2003). The Importance of the Project Method in Technology Education. Journal of Industrial Teacher Education, 40(3). https://scholar.lib.vt.edu/ejournals/JITE/v40n3/ 
Johnson, C. S., \& Delawsky, S. (2013). Project-based learning and student engagement. Academic Research International, 4(4), 560-570.

Kaur, R. S., \& Sawtantar, S. (2015). Exploring the Benefits of Cloud Computing Paradigm in Education Sector. International Journal of Computer Applications, 115(7), 1-3. https://doi.org/10.5120/20160-2217

Klein, D. (2002). Design projects for the classroom. The Technology Teacher, 61(4), 20-22.

Koch, F., Assunção, M. D., Cardonha, C., \& Netto, M. A. (2016). Optimizing resource costs of cloud computing for education. Future Generation Computer Systems, 55, 473-479. https://doi.org/10.1016/i.future.2015.03.013

Krivova, A. L., Kurbakova, S. N., Afanasyev, V. V., \& Rezakov, R. G. (2020). Capabilities of Cloud Services and Webinars Effectiveness of Teaching Humanities Students. Utopía Y Praxis Latinoamericana, 25(5), 135-146.

Lin, A., \& Chen, N. (2012). Cloud computing as an innovation: Perception, attitude, and adoption. The International Journal of Information Management, 32, 533-540. https://doi.org/10.1016/i.ijinfomgt.2012.04.001

Lyakhova, N. B., Avtsinova, G. I., Rustamov, F. H., \& Kamarova, N. S. (2020). Technology for conducting online lectures using clouds ervices in distance education for students of humanitarian specialties. EurAsian Journal of BioSciences, 14, 6189-6195.

Maida, C. A. (2011). Project-Based Learning: A Critical Pedagogy for the Twenty-First Century. Policy Futures In Education, 9(6), 759-768. https://doi.org/10.2304/pfie.2011.9.6.759

Majid, S., Liming, Z., Tong, S., \& Raihana, S. (2012). Importance of Soft Skills for Education and Career Success. International Journal for Cross-Disciplinary Subjects in Education, 2(2), $1036-1042$. https://doi.org/10.20533/ijcdse.2042.6364.2012.0147

Mansuri, A., Verma, M., \& Laxkar, P. (2014). Benefit of Cloud Computing for Educational Institutions and Online Marketing. Information Security and Computer Fraud, 2(1), 5-9.

Meirink, J. A., Imants, J., Meijer, P. C., \& Verloop, N. (2010). Teacher learning and collaboration in innovative teams. Cambridge Journal of Education, 40, 161-181. https://doi.org/10.1080/0305764x.2010.481256

Melnikova, M., Bychko, M., Komarevceva, I., Melnichuk, M., \& Dzhanbidaeva, Z. (2019). Legal education in the digital age: problems and prospects. JURÍDICAS CUC, 15(1), 301-320. http://dx.doi.org/10.17981/juridcuc.15.1.2019.11

Milovanova, M. M., Markova, T. S., Mushrub, V. A., Ordynskaya, M. E., \& Plaksa, J. V. (2020). Business education: training in the use of blockchain technology for business development. Revista Inclusiones, 7(Especial), 408-420.

Mircea, M. (2010). SOA, BPM and cloud computing: connected for innovation in higher education. In: 2010 International Conference on Education and Management Technology, Cairo, Egypt, pp. 456-460. https://doi.org/10.1109/ICEMT.2010.5657616

Mohammadi, H. (2015). Investigating users' perspectives on e-learning: An integration of TAM and IS success model. Computers in Human Behavior, 45, 359-374. https://doi.org/10.1016/j.chb.2014.07.044

Morales, T. M., Bang, E., \& Andre, T. (2013). A one-year case study: Understanding the rich potential of project-based learning in a virtual reality class for high school students. Journal of Science Education and Technology, 22(5), 791-806. https://doi.org/10.1007/s10956-012-9431-7

Odeh, M., Garcia-Perez, A., \& Warwick, K. (2017). Cloud Computing Adoption at Higher Education Institutions in Developing Countries: A Qualitative Investigation of Main Enablers and Barriers. International Journal of Information and Education Technology, 7(12), 921-927. https://doi.org/10.18178/ijiet.2017.7.12.996

Okai, S., Uddin, M., Arshad, A., Alsaqour, R., \& Shah, A. (2014). Cloud Computing Adoption Model for Universities to Increase ICT Proficiency. SAGE Open, July-September, 4(3), 1-10. https://doi.org/10.1177/2158244014546461

Ozdamlia, F., \& Bicen, H. (2014). Effects of training on Cloud Computing Services on M-Learning Perceptions and Adequacies. Procedia - Social and Behavioral Sciences, 116, 5115-5119. https://doi.org/10.1016/j.sbspro.2014.01.1083

Oliveira, A. M., Gerevini, A. M., \& Strohschoen, A. A. G. (2017). Diário de bordo: uma ferramenta metodológica para o desenvolvimento da alfabetização científica. Revista Tempos e Espaços em Educação, 10(22), 119-132.

Pardeshia, V. H. (2014). Cloud Computing for Higher Education Institutes: Architecture, Strategy and Recommendations for Effective Adaptation. Procedia Economics and Finance, 11, 589-599.

https://doi.org/10.1016/S2212-5671(14)00224-X 
Polutnik, J., Druzovec, M., \& Welzer, T. (2013). Interdisciplinary projects - Cooperation of students of different study programs. In: 2013 24th EAEEIE Annual Conference (EAEEIE 2013), Chania, Greece, pp. $215-218$. https://doi.org/10.1109/EAEEIE.2013.6576532

Ravitz, J., \& Blazevski, J. (2014). Assessing the role of online technologies in project-based learning. Interdisciplinary Journal of Problem-Based Learning, 8(1), 1-9. https://doi.org/10.7771/1541-5015.1410

Roberts, T., \& Harlin, J. (2007). The Project Method in Agricultural Education: Then and Now. Journal of Agricultural Education, 48(3), 46-56. https://doi.org/10.5032/jae.2007.03046

Rodrigues, B. M., Santos, J. E. B., \& Vasconcelos, C. A. (2020). Conceptions of undergraduate students in Chemistry on the use of interactive interfaces in and for the activities developed in the distance course. Journal of Research and Knowledge Spreading, 1(1), e11649.

Robertson, C. (2013). Using a cloud-based computing environment to support teacher training on common core implementation. Techtrends: Linking Research \& Practice to Improve Learning, 57(6), 57-60. https://doi.org/10.1007/s11528-013-0702-9

Sabi, H. M., Uzoka, F. E., Langmia, K., \& Njeh, F. N. (2016). Conceptualizing a model for adoption of cloud computing in education. The International Journal of Information Management, 36, 183-191. https://doi.org/10.1016/j.ijinfomgt.2015.11.010

Salam, A., \& Sardar, N. (2015). Cloud Based Learning Environment. International journal of advanced information science and technology, 4(6), 1-3.

Santos, J. E. B. (2020). Cartographic narratives: the teaching of mathematics and ICT. Journal of Research and Knowledge Spreading, 1(1), e11645

Sasikala, S., \& Prema, S. (2010). Massive Centralized Cloud Computing (MCCC) Exploration in Higher Education. Advances in Computational Sciences and Technology, 3(2), 111-118.

Sclater, N. (2010). eLearning in the Cloud. International Journal of Virtual and Personal Learning Environments, 1(1), 1019. https://doi.org/10.4018/jvple.2010091702

Shek, D. T., Leung, J. T., \& Merrick, J. (2017). Paradigm shift in youth development: Development of "soft skills" in adolescents. International Journal on Disability and Human Development, 16(4), 337-338. https://doi.org/10.1515/ijdhd-2017-7001

Silaeva, A. A., Panova, A. G., Evreeva, O. A., Lobazova, O. F., \& Azmetova, R. (2020). Designing a distance learning process: the use of cloud services for peer-to-peer interaction. Revista Inclusiones, 7(Especial), 513-525.

Sommerville, I. (2013). Teaching cloud computing: a software engineering perspective. Journal of Systems and Software, 86(9), 2330-2332. https://doi.org/10.1016/j .jss.2013.01.050

Sultan, N. (2010). Cloud computing for education: A new dawn? International Journal of Information Management, 30(2), 109-116. https://doi.org/10.1016/i.ijinfomgt.2009.09.004

Szállassy, N. (2008). Project Method, as one of the Basic Methods of Environmental Education. Acta Didactica Napocensia, 1(2), 44-49.

Thomas, P. Y. (2011). Cloud computing: A potential paradigm for practising the scholarship of teaching and learning. The Electronic Library, 29(2), 214-224. https://doi.org/10.1108/02640471111125177

Tomasz, L., \& Bajdor, P. (2015). The use of Cloud Computing by Students from Technical University - the Current State and Perspectives. Procedia Computer Science, 65, 1075-1084. https://doi.org/10.1016/i.procs.2015.09.050

Yadav, K. (2014). Role of Cloud Computing in Education. International Journal of Innovative Research in Computer and Communication Engineering, 2(2), 3108-3112.

Received: 15 January 2021 | Accepted: 13 February 2021 | Published: 27 February 2021 